\title{
Badanie postaw przedsiębiorczych studentów ekonomii
}

\section{Research on Entrepreneurial Attitudes of Students of Economics}

Streszczenie: Przedsiębiorczość jednostki staje się szczególnie ważna w chwili przejścia z etapu nauki do pierwszej stałej pracy zawodowej. Ten czas determinuje jej decyzje dotyczące aktywności zawodowej w przyszłości. Za kluczowe dla powodzenia inicjowanych przez jednostkę przedsięwzięć uznać należy jej wewnętrzne uwarunkowania, które koncentrują się na jej podmiotowych możliwościach, predyspozycjach do przejawiania przedsiębiorczej inicjatywy, pokonywania trudności czy radzenia sobie ze stresem. Celem opracowania jest ocena postaw przedsiębiorczych studentów ekonomii. Artykuł zawiera rozważania teoretyczne oraz wyniki badań empirycznych o charakterze pilotażowym. Badania ankietowe przeprowadzono na grupie studentów Wydziału Ekonomii Uniwersytetu Rzeszowskiego, przechodzącej z systemu edukacji na rynek pracy. Wyniki przeprowadzonych badań dowodzą, że respondenci deklarują cechy charakterystyczne dla osób przedsiębiorczych - swoje dyspozycje do bycia osobą przedsiębiorczą większość z nich ocenia na poziomie co najmniej przeciętnym. W celu skorzystania z potencjału młodych osób niezbędne jest wspieranie inicjatyw przedsiębiorczych przez kreowanie określonych warunków zarówno na poziomie makroekonomicznym, jak i wewnątrz organizacji, zwłaszcza jednak w ramach systemu edukacji.

\begin{abstract}
Entrepreneurship of the individual becomes particularly important at the stage of transition from the learning system to the first permanent professional work. This time determines the decisions regarding future professional activity. Internal conditions should be considered the key to the success of the initiated projects. They focus on the individual - his/her subjective capabilities, predispositions to manifest entrepreneurial initiative, overcome difficulties or cope with stress. The aim of the study is to assess the entrepreneurial attitudes of students of Economics. The article contains theoretical considerations and results of pilot empirical research. The survey was carried out on a group of students of Department of Economics from University of Rzeszów who are moving from the education system to the labour market. The results of the research conducted prove that the respondents declare features characteristic for entrepreneurial people - most of them assess their disposition to entrepreneurship as average at least. Hence, in order to take advantage of the potential of young people, it is necessary to support entrepreneurial initiatives by creating specific conditions both at the macroeconomic level and within the organisation, especially within the education system.
\end{abstract}


Słowa kluczowe: młode osoby; postawa przedsiębiorcza; przedsiębiorczość; tranzycja do rynku pracy

Keywords: entrepreneurial attitude; entrepreneurship; transition to the labour market; young people

Otrzymano: 3 kwietnia 2020

Received: 3 April 2020

Zaakceptowano: 31 lipca 2020

Accepted: 31 July 2020

\section{Sugerowana cytacja/Suggested citation:}

Mazurkiewicz, A. (2020). Badanie postaw przedsiębiorczych studentów ekonomii. Przedsiębiorczość - Edukacja [Entrepreneurship - Education], 16(2), 113-127. doi: 10.24917/20833296.162.9

\section{Wstęp}

Przedsiębiorczość aktualnie jest nie tylko pożądana - jest wręcz niezbędna do sprawnego funkcjonowania jednostek, organizacji, w tym zwłaszcza przedsiębiorstw, gospodarek oraz całych społeczeństw. Rozważana jest na poziomie indywidualnym, zespołowym, organizacyjnym, regionalnym, krajowym czy gospodarki. Zagadnienie to stanowi przedmiot zainteresowania wielu dziedzin i dyscyplin nauki, przede wszystkim ekonomii, prawa, socjologii, psychologii oraz nauk o zarządzaniu, z czego wynika niejednoznaczność w jego definiowaniu i interpretacji. Bez względu na przyjętą definicję należy stwierdzić za A. Bańką, że przedsiębiorczość nie polega na zaspokajaniu aktualnych potrzeb jednostki, lecz jest skierowana „na zaspokojenie celów przyszłościowych w aktualnych działaniach” (Bańka, 2007: 58).

Przedsiębiorczość staje się szczególnie ważna na etapie przejścia do pierwszej, stałej pracy zawodowej. Ten czas determinuje decyzje jednostki dotyczące jej aktywności zawodowej w przyszłości. Cechuje go m.in. poszukiwanie własnej tożsamości czy eksperymentowanie na rynku pracy. Istotna jest zatem zwłaszcza odpowiedzialność za własne życie oraz przedsiębiorczość w ustalaniu i realizacji celów.

Za kluczowe dla powodzenia inicjowanych przez jednostkę przedsięwzięć uznać należy jej wewnętrzne uwarunkowania - podmiotowe możliwości, predyspozycje do przejawiania przedsiębiorczej inicjatywy, pokonywania trudności czy radzenia sobie ze stresem. Stąd w niniejszym artykule skoncentrowano się na przedsiębiorczości jako postawie.

Celem artykułu jest ocena postaw przedsiębiorczych studentów ekonomii. Analizę przeprowadzono, uwzględniając następujące obszary:

- potrzeba osiągnięć w biznesie,

- innowacyjność,

- poczucie kontroli osobistej,

- samoocena.

Artykuł zawiera rozważania teoretyczne przeprowadzone na podstawie analizy literatury przedmiotu oraz wyniki badań empirycznych o charakterze pilotażowym. Badaniami objęto grupę studentów Wydziału Ekonomii Uniwersytetu Rzeszowskiego, przechodzącej z systemu edukacji na rynek pracy. Tak jak wspomniano wyżej, w artykule skoncentrowano się na przedsiębiorczości w kontekście postawy. Zaprezentowano i poddano analizie wyniki badań empirycznych. 


\section{Przedsiębiorczość jako postawa}

Pojęciu przedsiębiorczości poświęcono wiele miejsca w literaturze przedmiotu. Wielość definicji i ujęć umożliwia analizę tej kategorii w aspekcie (Piecuch, 2013):

- postawy - ujęcie to akcentuje cechy charakterystyczne dla przedsiębiorczych osób;

- działania - stanowiącego specyficzny rodzaj aktywności ukierunkowany na zmianę stanu istniejącego, w wyniku m.in. realizacji pomysłów, wykorzystywania okazji niedostrzeganych lub ignorowanych przez inne osoby (Klonowska-Matynia, Palinkiewicz, 2013; Łochnicka, 2016);

- procesu - w tym ujęciu istotą przedsiębiorczości jest tworzenie i rozwój podmiotów gospodarczych. Akcentowane są działania podejmowane przez przedsiębiorcę, umożliwiające realizację przyjętych celów.

Podejścia te są ze sobą ściśle związane i uzupełniają się wzajemnie. Działania przedsiębiorcze stanowią rezultat indywidualnych postaw. Z kolei proces przedsiębiorczy możliwy jest w wyniku podjęcia działań przez jednostki charakteryzujące się przedsiębiorczymi cechami (Łochnicka, 2016). Fundament, na którym powstaje i rozwija się przedsiębiorczość, stanowią zatem odpowiednie postawy. Tak jak powiedziano wcześniej - za kluczowe dla powodzenia inicjowanych przez jednostkę przedsięwzięć uznać należy jej wewnętrzne uwarunkowania (Piecuch, 2013).

Postawa przedsiębiorcza jest definiowana jako „skłonność jednostki do angażowania się w innowacyjne, proaktywne i ryzykowne działania w celu podjęcia nowego przedsięwzięcia” (Vinig, Dorresteijn, 2007). Charakterystyczne są dla niej: autonomia, innowacyjność, proaktywność i agresywność konkurencyjna (Vinig, Dorresteijn, 2007). Postawa przedsiębiorcza uwarunkowana jest również kulturą narodową (Scheiner, 2009; za: Łuczka, 2011).

Przedsiębiorczość jako postawa odzwierciedla się w twórczym działaniu, w zmierzaniu do poprawy status quo, w gotowości do podejmowania nowych działań czy poszerzania zakresu dotychczasowych. W rezultacie oznacza dążenie do osiągnięcia zwiększonych i bardziej złożonych korzyści materialnych, czego konsekwencją jest poprawa warunków życia i pracy (Wiatrak, 2003).

Interpretacja przedsiębiorczości jako postawy odnosi się do indywidualnych cech, takich jak: zdolności intelektualne, wysoka motywacja do odnoszenia sukcesów, zdolność abstrakcyjnego myślenia, zdolność przewidywania, potrzeba dominacji, skłonność do podejmowania ryzyka, gotowość do przyswajania nowej wiedzy, posiadanie „niespokojnego” umysłu, zdolność obserwacji otoczenia i dostrzegania zagadnień wymagających zmiany, umiejętność przystosowania się do zmiennych warunków, umiejętność nawiązywania relacji z otoczeniem, umiejętność korzystania z każdej sposobności do twórczego działania, zdecydowane i odpowiedzialne postępowanie wobec innych osób, odwaga czy determinacja i przekonanie o własnych możliwościach (Gołębiewska, 2009; Kapusta, 2006; Oleksyn, 2006; Wiatrak, 2003; Żur, 2006). Wiele definicji przedsiębiorczości akcentuje znaczenie określonych cech, charakterystycznych dla przedsiębiorczej postawy. Katalog tych cech nie jest zamknięty, stwierdzić jednak należy, że przedsiębiorczości sprzyja podejście dynamiczne, otwarte na podejmowanie spontanicznych i niestandardowych działań.

Mimo że na realizację procesu przedsiębiorczego oddziałują zarówno uwarunkowania wewnętrzne, jak i zewnętrzne, to na podstawie analizy literatury przedmiotu za kluczowe czynniki kształtujące ten proces uznać należy uwarunkowania indywidulane w postaci postawy przedsiębiorczej. 
Zagadnienie przedsiębiorczości w niniejszym opracowaniu odnoszone jest do aktualnych i potencjalnych pracowników. Jest ono szczególnie ważne w odniesieniu do młodych osób, przechodzących z etapu edukacji do życia zawodowego. Ten etap życia jednostki, określany jako „wyłaniająca się dorosłość”, cechuje m.in. brak wykrystalizowania poczucia tożsamości czy wzmożone eksperymentowanie na rynku pracy. Istotne znaczenie ma w nim zatem przedsiębiorczość w ustalaniu i realizacji celów oraz zdolność do samozatrudnienia (Bańka, 2007).

Postawa przedsiębiorcza młodych osób jest istotna także w kontekście zmian dokonujących się na rynku pracy. Z jednej strony poszukuje się rozwiązań równoważących „kryzys pracy etatowej” (Pluta, Safin, 2016), która stanowi najbardziej atrakcyjną formę zatrudnienia dla młodych osób (Infuture Institute, 2019; GUS, 2019), a także ograniczających zwiększone ryzyko ich pozostawania bez pracy w porównaniu z osobami bardziej dojrzałymi (co stanowi wynik braku doświadczenia i wiedzy dotyczącej określonego zawodu) (Braziene, Merkys, Mikutaviciene, 2014). Ponadto znacznie mniej definiowalne i przewidywalne stały się możliwości rozwoju zawodowego, częściej dochodzi do zmiany zawodu (Guthridge, Komm, Lawson, 2008; Savickas i in., 2009). Odpowiedzialność za działania podejmowane w sferze zawodowej przesunięta została w stronę jednostki, która we własnym zakresie negocjuje kontrakt psychologiczny. Jednocześnie akcentuje się przejście od długoterminowych relacji między jednostką a organizacją do relacji krótkoterminowych (Bohdziewicz, 2010). Definiowanie celów kariery, poszukiwanie pracy i odkrywanie oczekiwań w nowej roli - zawodowej stanowią wyzwania dla osób wstępujących na rynek pracy (Mackenzie Davey, Arnold, 2000). Przejście do pierwszej, stałej pracy pozostaje najbardziej znaczącym wydarzeniem w rozwoju człowieka - jej przebieg decyduje o dalszej przedsiębiorczości jednostki, jej otwartości na nowe doświadczenia oraz zdolności do samozatrudnienia. Jest to zatem czas, który determinuje decyzje dotyczące aktywności zawodowej w przyszłości (Bańka, 2007). Podjęcie tej aktywności przez młode osoby stanowi dla nich najważniejsze zadanie, warunkujące rozwiązanie pozostałych problemów związanych z przechodzeniem do dorosłości - praca oddziałuje przede wszystkim na rozwój osobowy, życie rodzinne oraz rozwój zawodowy i karierę (Wiatrowski, 2009). Jednocześnie wśród pożądanych umiejętności w przyszłości wymieniane są umiejętności ściśle powiązane z przedsiębiorczością, w tym: zdolność do aktywnego uczenia się, kreatywność, umiejętność dzielenia się wiedzą, współpraca czy nastawienie na rozwiązywanie problemów. Młode osoby deklarują, że dla nich najważniejsza w pracy jest kreatywność (Infuture Institute, 2019).

Zwiększenie znaczenia kompetencji miękkich potwierdzają również analizy makroekonomiczne. Wzrost liczby mikroprzedsiębiorstw oraz ich udziału w sektorze przedsiębiorstw, specyfika prowadzonej działalności i jednocześnie coraz mniejsza przeżywalność przedsiębiorstw pierwszego roku działalności (PARP, 2019b) dowodzą konieczności zwrócenia uwagi na przedsiębiorczość indywidualnych osób. Równocześnie prowadzenie własnego przedsiębiorstwa stanowi najbardziej atrakcyjną formę aktywności zawodowej dla 28\% osób w wieku do 22 lat (Infuture Institute, 2019).

W grupie osób w wieku 20-24 lata stopa bezrobocia w Polsce w I kwartale 2019 r. wyniosła 9,8\% (populacja osób bezrobotnych w tej grupie wieku liczyła 112 tys.), przy czym wśród bezrobotnych było więcej kobiet - 11,7\%; odsetek bezrobotnych mężczyzn wyniósł 
8,4\%. Przedstawione wartości są znacznie wyższe od ustalonych dla całej populacji, które wyniosły odpowiednio: 3,9\% ogółem, 3,4\% dla mężczyzn i 4,6\% dla kobiet. Sytuacja młodych osób na rynku pracy jest mniej korzystna niż pozostałych (GUS, 2019). Ponadto osoby te są bardziej podatne na negatywne zmiany na tym rynku (Koptiew, 2014).

\section{Rola szkolnictwa wyższego w kształtowaniu postaw przedsiębiorczych}

W kontekście przeprowadzonych rozważań istotna staje się rola systemu edukacji, zwłaszcza szkół wyższych, w kształtowaniu postaw przedsiębiorczych. Jest konieczne, aby szkoły te spełniały stawiane im wymagania oraz swoją funkcję dotyczącą kształcenia przyszłych kadr zdolnych do samodzielnego, elastycznego i kreatywnego działania, a przez to - wspierania rozwoju gospodarki opartej na wiedzy. Uczelnie aktualnie nie realizują wyłącznie misji kształcenia i rozwoju, nauka „staje się istotnym czynnikiem rozwoju gospodarczego, gdyż przyczynia się do tworzenia innowacji i rozwoju przedsiębiorstw opartych na nowoczesnych technologiach" (Buchta, Jakubiak, 2014: 169). Studenci w trakcie studiów, według wyników badań J.M. Moczydłowskiej i E. Pycz (Moczydłowska, Pycz, 2017), w największym stopniu rozwijają umiejętność pracy zespołowej, komunikowania się, pracy w warunkach stresu, a także samodzielność. Umiejętność kreatywnego myślenia, istotna dla przedsiębiorczej aktywności, rozwijana jest w mniejszym stopniu. Jednocześnie zajęcia z przedsiębiorczości realizowane w ramach studiów pozytywnie ocenia tylko $17 \%$ studentów. Akcentuje się, że nauczanie przedsiębiorczości nadmiernie koncentruje się na przekazywaniu wiedzy z zakresu zakładania i prowadzenia przedsiębiorstw, w niedostatecznym stopniu natomiast przyczynia się do kształtowania postaw przedsiębiorczych, a w rezultacie - do postrzegania siebie na rynku pracy jako pracodawcy (Bizon i in., 2013).

Niezbędne staje się zatem skorzystanie z dodatkowych rozwiązań, polegających m.in. na praktycznym wykorzystaniu pozyskanej wiedzy, takich jak studia przypadku, symulacje biznesowe, rozwiązywanie rzeczywistych problemów występujących w funkcjonowaniu przedsiębiorstw w określonym regionie czy wieloaspektowa analiza gospodarki rynkowej (Bizon i in., 2013). Ponadto cenne jest korzystanie z oferty biura karier, inkubatorów przedsiębiorczości, centr transferu technologii oraz pozauczelnianych instytucji otoczenia biznesu (Buchta, Jakubiak, 2014), jak również z międzynarodowych dokonań. Doświadczenia krajów, które wdrożyły rozwiązania sprzyjające kształtowaniu przedsiębiorczych postaw i podejmowaniu przedsiębiorczych działań, wskazują, że skuteczne są m.in.:

- międzydyscyplinarne uczelniane programy prowadzone przez wykładowców, angażujące studentów w celu opracowania dochodowych produktów, a następnie ulokowania ich na rynku,

- programy nauki dla studentów innych dyscyplin, wypracowujące podstawowe umiejętności w zakresie przedsiębiorczości i zarządzania, od rozpoznawania możliwości po komercjalizację,

- programy realizowane przez uczelnie wspólnie z instytucjami podejmującymi działania edukacyjne dotyczące przedsiębiorczości, w tym m.in. instytucjami artystycznymi,

- systematyczne warsztaty, spotkania służące wymianie doświadczeń,

- kursy wspierające naukę kreatywności przez udział w warsztatach, studia przypadków, projekty zespołowe, wycieczki terenowe i wykłady prowadzone przez ekspertów,

- programy, których celem jest rozpoczęcie przedsięwzięć komercyjnych i non profit, 
umożliwiające współpracę studentów z ekspertami, przedsiębiorcami, studentami studiów MBA (Kauffman. The Foundation of Entrepreneurship, 2019).

Ponadto akcentuje się wykorzystanie symulacji komputerowych w nauczaniu przedsiębiorczości, aby przedsiębiorcy i studenci doświadczali złożonych relacji biznesowych i zarządzania innowacjami w środowisku wolnym od ryzyka (Lendner, Hübscher, 2009).

Nauczanie przedsiębiorczości może koncentrować się na rozwijaniu kompetencji przedsiębiorczych w celu założenia własnej działalności gospodarczej. Przedstawione rozwiązania można określić jako naukę przedsiębiorczości przez działanie. Edukacja w tym zakresie nie powinna ograniczać się do zdobycia profesjonalnej wiedzy, umiejętności i zdolności, powinna obejmować również inne formy uczenia się, mające na celu szkolenie, specjalizację i rozwój osobisty, realizowane w instytucjach edukacji dorosłych, przedsiębiorstwach, stowarzyszeniach, klubach sportowych i innych, które działają niezależnie od formalnego systemu edukacji. Istotną rolę w rozwoju zachowań przedsiębiorczych odgrywa wymiana wiedzy w rodzinie, wśród przyjaciół, rówieśników, a także uczenie się od wzorców do naśladowania i mentorów (Podrug i in., 2015).

Cenne są również studia doktoranckie, podyplomowe oraz studia MBA w zakresie przedsiębiorczości. Jak dowodzą międzynarodowe doświadczenia, edukacja odgrywa istotną rolę w zakresie przedsiębiorczości, przy czym szczególnie ważne są działania związane z generowaniem, krytyczną oceną i ostatecznym wdrażaniem pomysłów biznesowych (Autio i in., 2001). Stąd ważna jest rola uniwersytetów we wdrażaniu i komercjalizacji wyników badań, powstawaniu start-upów i spin-offów o dużym potencjale wzrostu (World Economic Forum, 2009). Uczelnie powinny zatem wspierać postawy i zachowania przedsiębiorcze przez tworzenie świadomości, przekazywanie wiedzy i stymulowanie oraz ocenianie pomysłów do ich realizacji.

Decyzje dotyczące usprawnienia funkcjonujących rozwiązań lub wdrożenia nowych powinny uwzględniać specyfikę kierunku studiów. Wyniki badań wskazują na zróżnicowanie wśród studentów dotyczące przedsiębiorczych postaw i aktywności, szczególnie pod względem kryterium płci oraz kierunku studiów. Ogólnie można stwierdzić, że mężczyźni częściej niż kobiety postrzegają siebie jako osoby przedsiębiorcze (Korpysa, 2007; Moczydłowska, Pycz, 2017), są też bardziej aktywni i zakładają więcej podmiotów gospodarczych (Łuczka, 2011). Czynnikiem różnicującym w większym stopniu samoocenę przedsiębiorczości jest kierunek studiów - studenci kierunków ekonomicznych w większym stopniu oceniają się jako osoby przedsiębiorcze niż studenci innych kierunków społecznych czy humanistycznych (Korpysa, 2007), przy czym nie występuje tu różnica w porównaniu ze studentami kierunków technicznych (Wyrwa, Sołtysiak, 2016). Kierunek studiów jest również ważny przy uwzględnianiu planów dotyczących prowadzenia własnej działalności gospodarczej - deklaruje tak większy odsetek studentów kierunku zarządzania niż innych kierunków związanych z zarządzaniem, takich jak logistyka (Moczydłowska, Pycz, 2017). Zagadnienie to stanowi obszar zainteresowań mniejszości studentów kierunków ekonomicznych w Polsce - około 1/3 badanych (Kraśnicka i in., 2014; Wyrwa, Sołtysiak, 2016). Wyniki badań pilotażowych przeprowadzonych przez A. Arent i A. Walczynę (2014) na kierunkach związanych z zarzadzaniem wskazały na mniejszy odsetek studentów zainteresowanych założeniem własnej działalności gospodarczej - 26,1\%. Wyjątkowo wysoki odsetek pozytywnych odpowiedzi (54\%) otrzymały w swoich badaniach K. Buchta i M. Jakubiak (2014), które skoncentrowały uwagę na studentach kierunków zaliczanych do medycznych, przy czym uzyskane przez nie wyniki 
wskazywały, że niemal połowa osób z deklarujących chęć założenia własnej działalności gospodarczej nie była zdecydowana w sprawie terminu rozpoczęcia tej działalności.

Jednocześnie studenci kierunków technicznych deklarują częściej posiadanie pomysłu na własną działalność gospodarczą (40\%) niż studenci kierunków ekonomicznych $(28,9 \%)$ (Wyrwa, Sołtysiak, 2016), co może być związane ze specjalistycznymi umiejętnościami nabywanymi przez nich podczas studiów. Studenci studiów ekonomicznych w większym stopniu niż pozostali uczestniczą w wydarzeniach, takich jak Targi Pracy, które motywują do kształtowania postaw przedsiębiorczych (Dąbrowska, Skowron, 2015).

Przedstawione różnice wynikają z faktu, że na kierunkach ekonomicznych łatwiejszy jest dostęp do zajęć dydaktycznych związanych przedsiębiorczością, jak również w większym stopniu są promowane wydarzenia umożliwiające rozwój kariery zawodowej. Studenci tych kierunków jednocześnie posiadają wiedzę dotyczącą prowadzenia własnej działalności gospodarczej i mają świadomość ryzyka oraz trudów z tym związanych. Przypuszczać zatem należy, że studenci kierunków ekonomicznych uzyskają relatywnie wysokie - ponadprzeciętne - oceny swoich przedsiębiorczych predyspozycji, co w przyszłości niekoniecznie przełoży się na założenie przez nich własnej działalności, lecz odzwierciedlać się może zwłaszcza w intraprzedsiębiorczości.

\section{Narzędzie badawcze}

Przeprowadzone badania stanowiły część badań dotyczących postaw przedsiębiorczych w zarządzaniu karierą zawodową. Charakteryzowane w niniejszym artykule narzędzie jest fragmentem rozwiązania opracowanego dla potrzeb realizacji badań; pozostałe aspekty dotyczyły kariery zawodowej i jej uwarunkowań.

W badaniach nad postawą przedsiębiorczą studentów zastosowano kwestionariusz postawy przedsiębiorczej (The Entrepreneurial Attitude Orientation - EAO), pozwalający na predykcję zachowań przedsiębiorczych, którego autorami są P.B. Robinson, D.V. Stimpson, J.C. Huefner i H.K. Hunt (Robinson i in., 1991). Kwestionariusz zawiera 75 stwierdzeń, które w przyjętej adaptacji oceniane były w pięciostopniowej skali od 1 („,całkowicie się nie zgadzam”) do 5 („całkowicie się zgadzam”). Zastosowanie mniejszej skali niż oryginalna dziesięciostopniowa skala uzasadnione było potrzebami wynikającymi z celu badania, jak również standaryzacją narzędzia badawczego oraz ograniczeniem czasochłonności jego użycia.

Narzędzie składa się z czterech podskal, którymi są:

- potrzeba osiągnięć w biznesie (need for achievement in business), skala dotycząca określonych rezultatów związanych z założeniem i prowadzeniem własnej działalności na podstawie 23 stwierdzeń,

- innowacyjność (innovation), skala związana z postrzeganiem i podejmowaniem aktywności w nowy i unikalny sposób, gdzie ocena jest dokonywana na podstawie 26 stwierdzeń,

- poczucie kontroli osobistej (perceived personal control), skala odnosząca się do postrzegania kontroli i swojego wpływu na podejmowane działania, której dotyczyło 12 stwierdzeń,

- samoocena (self-esteem), skala oznaczająca pewność siebie i postrzeganie własnych kompetencji, do której odnosiło się 14 stwierdzeń. 
Prezentowane narzędzie stosowane jest do oceny szeroko interpretowanych predyspozycji przedsiębiorczych, związanych z zamiarem podjęcia działalności gospodarczej, stania się przedsiębiorcą/pracodawcą, nie dotyczy ono natomiast oceny przedsiębiorczych działań.

\section{Wyniki badań pilotażowych}

Badania o charakterze pilotażowym przeprowadzono w czerwcu 2019 r. na Wydziale Ekonomii Uniwersytetu Rzeszowskiego, z zastosowaniem praw anonimowości i dobrowolności osób badanych. Do badań zaproszono 90 studentów przechodzących z uczelni na rynek pracy - udział w nich wzięli studenci studiów drugiego stopnia ${ }^{1}$. Zwrotnie otrzymano 84 (93,3\%) kompletnie wypełnione kwestionariusze ankiet. Wśród respondentów przeważały kobiety, które stanowiły ponad $82 \%$ badanych. Przedstawione proporcje, wyznaczone według kryterium płci, odpowiadają strukturze studentów i wynikają ze specyfiki kierunków studiów, na których przeprowadzono badania.

Przeciętne doświadczenie zawodowe respondentów wyniosło niecałe 10 miesięcy, przy czym ponad połowa osób (56\%) nie podjęła do momentu przeprowadzenia badań jakiejkolwiek aktywności zawodowej. Osoby posiadające to doświadczenie przeciętnie pracowały 1,8 roku. 95,2\% ankietowanych stanowiły osoby stanu wolnego, tylko cztery osoby były zamężne/żonate. Pod względem miejsca zamieszkania większość respondentów była mieszkańcami wsi (63\%), co odzwierciedla strukturę ludności w województwie podkarpackim ze względu na miejsce zamieszkania, w którym przeważa ludność rolnicza.

Po sprawdzeniu normalności rozkładu za pomocą testów Kołmogorowa-Smirnowa i Shapiro-Wilka (Sobczyk, 2000) dla każdej grupy oraz wyników całościowych spełnione zostały założenia o rozkładzie normalnym - obliczono średnie sumy punktów z odpowiedzi udzielonych na stwierdzenia określające każdy z wyodrębnionych aspektów odróżniających osoby przedsiębiorcze od pozostałych osób: potrzebę osiągnięć w biznesie, innowacyjność w biznesie, poczucie kontroli osobistej oraz samoocenę. Odniesiono się również do postawy przedsiębiorczej ogółem (tabela 1). Uwzględniono podział badanej grupy ze względu na płeć.

Tabela 1. Postawy przedsiębiorcze respondentów - średnie wyniki odpowiedzi

\begin{tabular}{|l|c|c|c|c|c|c|}
\hline \multirow{2}{*}{ Wyszczególnienie } & \multicolumn{2}{|c|}{ Kobiety } & \multicolumn{2}{c|}{ Mężczyźni } & \multicolumn{2}{c|}{ Ogółem } \\
\cline { 2 - 7 } & średnia & $\begin{array}{c}\text { odchylenie } \\
\text { standardowe }\end{array}$ & średnia & $\begin{array}{c}\text { odchylenie } \\
\text { standardowe }\end{array}$ & średnia & $\begin{array}{c}\text { odchylenie } \\
\text { standardowe }\end{array}$ \\
\hline Potrzeba osiągnięć & 88,5 & 9,5 & 83,8 & 9,3 & 87,6 & 9,6 \\
\hline Innowacyjność & 85,4 & 9,4 & 88,6 & 8,7 & 86,0 & 9,3 \\
\hline $\begin{array}{l}\text { Poczucie kontroli } \\
\text { osobistej }\end{array}$ & 40,7 & 4,0 & 42,1 & 5,4 & 41,0 & 4,3 \\
\hline Samoocena & 46,6 & 4,8 & 45,9 & 7,7 & 46,0 & 5,4 \\
\hline Ogółem & 261,2 & 20,9 & 260,3 & 20,2 & 261,0 & 20,7 \\
\hline
\end{tabular}

Źródło: opracowanie własne

${ }^{1}$ Osoby te spełniają kryterium psychologiczne wieku wyłaniającej się dorosłości (18-25 lat), przedstawione przez Bańkę (2007). Jednocześnie spełniają kryterium ekonomiczne wieku osób młodych (20-24 lata) przyjęte przez GUS (2019). 
W dalszej kolejności przystąpiono do opracowania na podstawie otrzymanych wyników skali typu sten. Ustalono progi ocen dla postawy przedsiębiorczej ogólnie (tabela 2) oraz poszczególnych aspektów postawy przedsiębiorczej (tabela 3). Wyznaczono progi dla wyników niskich (1-2 sten), poniżej przeciętnej (3-4 sten), przeciętnych (5-6 sten), ponadprzeciętnych (7-8 sten) oraz wysokich (9-10 sten).

Tabela 2. Progi ocen skali dla postawy przedsiębiorczej respondentów ogólnie

\begin{tabular}{|l|c|c|c|}
\hline Wyszczególnienie & $\begin{array}{c}\text { Przedziały } \\
\text { wyników }\end{array}$ & $\begin{array}{c}\text { Ocena } \\
\text { wyników }\end{array}$ & $\begin{array}{c}\text { Odsetek } \\
\text { odpowiedzi }\end{array}$ \\
\hline \multirow{4}{*}{$\begin{array}{l}\text { Postawa } \\
\text { przedsiębiorcza }\end{array}$} & powyżej 289 & wysokie & $2,4 \%$ \\
\cline { 2 - 4 } & $272-289$ & ponadprzeciętne & $33,3 \%$ \\
\cline { 2 - 4 } & $250-271$ & przeciętne & $35,7 \%$ \\
\cline { 2 - 4 } & $230-249$ & poniżej przeciętnej & $21,4 \%$ \\
\cline { 2 - 4 } & poniżej 230 & niskie & $7,1 \%$ \\
\hline
\end{tabular}

Źródło: opracowanie własne

Wyniki przeprowadzonych badań dowodzą, że zdecydowana większość badanych osób (ponad 71,4\%) oceniła swoje predyspozycje do bycia przedsiębiorczym na poziomie co najmniej przeciętnym, a połowa $\mathrm{z}$ nich postrzegała je na poziomie wyższym od przeciętnego. Przy możliwych do uzyskania wynikach, mieszczących się w przedziale od 75 do 375 , minimalna wartość udzielonych odpowiedzi wyniosła 212, natomiast maksymalna - 303. W ocenie nie występowały różnice między mężczyznami a kobietami. Otrzymane wyniki świadczą o znacznym przekonaniu studentów, że są osobami przedsiębiorczymi - swoje predyspozycje w tym względzie na poziomie niższym niż przeciętny określiła $1 / 4$ respondentów, pozostała część, w takiej samej proporcji, określiła je jako przeciętne lub wyższe. Do zbliżonych wniosków dotyczących wysokiej oceny własnych przedsiębiorczych predyspozycji doszli również inni autorzy badający studentów (Korpysa, 2007; Moczydłowska, Pycz, 2017).

Tabela 3. Progi ocen skali dla poszczególnych aspektów postawy przedsiębiorczej respondentów

\begin{tabular}{|l|l|l|c|}
\hline Wyszczególnienie & \multicolumn{1}{|c|}{$\begin{array}{c}\text { Przedziały } \\
\text { wyników }\end{array}$} & \multicolumn{1}{c|}{$\begin{array}{c}\text { Ocena } \\
\text { wyników }\end{array}$} & $\begin{array}{c}\text { Odsetek } \\
\text { odpowiedzi }\end{array}$ \\
\hline \multirow{4}{*}{ Potrzeba osiągnięćc } & powyżej 101 & wysokie & $1,2 \%$ \\
\cline { 2 - 4 } & $93-101$ & ponadprzeciętne & $36,9 \%$ \\
\cline { 2 - 4 } & $82-92$ & przeciętne & $33,3 \%$ \\
\cline { 2 - 4 } & $74-81$ & poniżej przeciętnej & $22,6 \%$ \\
\cline { 2 - 4 } & poniżej 74 & niskie & $6,0 \%$ \\
\hline \multirow{5}{*}{ Innowacyjność } & powyżej 99 & wysokie & $6,0 \%$ \\
\cline { 2 - 4 } & $91-99$ & ponadprzeciętne & $26,2 \%$ \\
\cline { 2 - 4 } & $81-90$ & przeciętne & $45,2 \%$ \\
\cline { 2 - 4 } & $73-80$ & poniżej przeciętnej & $16,7 \%$ \\
\cline { 2 - 4 } & poniżej 73 & niskie & $6,0 \%$ \\
\hline
\end{tabular}




\begin{tabular}{|l|l|l|c|}
\hline \multirow{3}{*}{$\begin{array}{l}\text { Poczucie kontroli } \\
\text { osobistej }\end{array}$} & powyżej 47 & wysokie & $7,1 \%$ \\
\cline { 2 - 4 } & $44-47$ & ponadprzeciętne & $20,2 \%$ \\
\cline { 2 - 4 } & $39-43$ & przeciętne & $42,9 \%$ \\
\cline { 2 - 4 } & $35-38$ & poniżej przeciętnej & $22,6 \%$ \\
\cline { 2 - 4 } & poniżej 35 & niskie & $7,1 \%$ \\
\hline Samoocena & powyżej 53 & wysokie & $6,0 \%$ \\
\cline { 2 - 4 } & $50-53$ & ponadprzeciętne & $22,6 \%$ \\
\cline { 2 - 4 } & $44-49$ & przeciętne & $39,3 \%$ \\
\cline { 2 - 4 } & $39-43$ & poniżej przeciętnej & $23,8 \%$ \\
\cline { 2 - 4 } & poniżej 39 & niskie & $8,3 \%$ \\
\hline
\end{tabular}

Źródło: opracowanie własne

Wśród analizowanych obszarów postawy przedsiębiorczej (tabela 1) ankietowani bardzo mocno odczuwają potrzebę osiągnięć (średnia 87,6, odchylenie standardowe 9,6). W tym obszarze minimalna wartość uzyskanych wyników wyniosła 60, maksymalna - 106 (przedział wyników możliwych do uzyskania wynosił od 23 do 115). Największy odsetek respondentów ocenił tę predyspozycję wyżej od przeciętnej, 1/3 respondentów oceniła ją jako przeciętną, przy czym kobiety uzyskały wyższe oceny niż mężczyźni. Taki wynik oznacza, że badani studenci odczuwali w dużym stopniu potrzebę wykonywania czynności szybko i poprawnie, aby osiągnąć lub przekroczyć wysokie standardy (Bańka, 2016) oraz deklarowali gotowość do przezwyciężania przeszkód. Wiąże się to z pozytywnymi emocjami odczuwanymi jako rezultat korzystania $z$ własnych umiejętności i ich rozwoju (Wojdyło, Retowski, 2012). Jednostki o silnej potrzebie osiągnięć dążą przede wszystkim do jak najlepszego wykonania określonej pracy, nie zależy im (lub zależy w mniejszym stopniu niż osobom o niskiej motywacji osiągnięć) na nagrodach stanowiących rezultat tego wykonania (Widerszal-Bazyl, 1979). Silna potrzeba osiągnięć oznacza zainteresowanie nie osiąganym celem, lecz tym, że cel ten stanowi miarę sukcesu (Reykowski, 1977). Wysoka ocena w tym obszarze jest związana z zadowoleniem $\mathrm{z}$ indywidualnych osiągnięć i motywuje do dalszych sukcesów, przekraczania kolejnych standardów.

W mniejszym stopniu badane osoby postrzegały możliwość wpływu na swój wkład w podejmowane działania. Otrzymane wyniki (średnia 41,0, odchylenie standardowe 4,3, minimalna wartość 32, maksymalna 49 w przedziale możliwych do uzyskania wyników od 12 do 60) świadczą jednak o relatywnie silnym przekonaniu o własnych możliwościach oraz stopniu decydowania o swoim losie przy niewielkim doświadczeniu życiowym i zawodowym (lub jego braku). Niemal 43\% respondentów oceniło swoje predyspozycje w tym zakresie jako przeciętne, ponad $1 / 4$ jako wyższe niż przeciętne, natomiast prawie $30 \%$ z nich jako niskie. Przekonanie o własnych możliwościach skutecznego działania jest istotne w kontekście przedsiębiorczości, gdyż wpływa na aktywność jednostki. Subiektywne przekonanie o sprawowanej kontroli stanowi podstawę precyzowania oczekiwań dotyczących rezultatów własnego działania. Otrzymane wyniki świadczą o tym, że badane osoby w większości wyrażały co najmniej przeciętne przekonanie, że uzyskiwane wyniki zależą głównie od ich osobistego wkładu.

Wyniki uzyskane dla samooceny i innowacyjności w biznesie uznać należy za umiarkowanie satysfakcjonujące. Dla poczucia własnej wartości (średnia 46,0, odchylenie standardowe 5,4) uzyskano wyniki mieszczące się w przedziale od 36 do 61, przy wynikach możliwych do uzyskania w przedziale od 14 do 70 . Zróżnicowanie odpowiedzi dotyczące 
poczucia własnej wartości nie było duże, jednak nieznacznie wyższe deklarowały kobiety, co oznacza, że śmielej patrzyły one w przyszłość. Wprawdzie nie jest korzystne ani zaniżone, ani zawyżone poczucie własnej wartości - oba przypadki związane są z negatywnymi konsekwencjami - jednak wysoki poziom samooceny motywuje do podejmowania ambitnych działań, stanowiących wyzwanie, jednocześnie w sytuacji nieuniknionej porażki skłania do przerwania podjętej aktywności. Świadomość własnej wartości umożliwia przejęcie przez jednostkę kontroli nad swoim postępowaniem, które może prowadzić do sukcesu (Góralewska-Słońska, 2011). Samoocena ma duże znaczenie, zwłaszcza dla młodych osób, ponieważ stanowi ona podstawę do przemyśleń zarówno nad posiadanymi atutami, jak i ograniczeniami, także w sferze zawodowej.

W ostatnim obszarze poddanym analizie - innowacyjności w biznesie - otrzymano wyniki w przedziale od 60 do 108, przy możliwym zakresie od 26 do 130 (średnia wyniosła 86, odchylenie standardowe 9,3). Wyższe oceny przydzielili sobie mężczyźni, co oznacza, że byli oni bardziej skłonni realizować działania w unikalny, niestandardowy sposób. Zagadnienie to jest szczególnie istotne dla sukcesu podejmowanych przedsięwzięć gospodarczych, gdyż - jak twierdzą przedsiębiorcy - zindywidualizowane podejście do klienta oraz wysoka jakość obsługi stanowią podstawę powodzenia (Cieślik, 2014). Zdolność zasadniczej zmiany przyjętej koncepcji działania oraz realizowanych przedsięwzięć w celu dostosowania się do indywidualnych oczekiwań klientów wymaga kreatywnego podejścia zwłaszcza od właściciela i kadry zarządzającej, którzy stymulują działania innowacyjne i są głównymi kreatorami w polskich przedsiębiorstwach (PARP, 2019a), a także od pracowników niższych szczebli.

\section{Podsumowanie}

Celem artykułu była ocena postaw przedsiębiorczych studentów ekonomii. Analiza wyników przeprowadzonych badań wykazała, że zdecydowana większość badanych osób przechodzących z etapu nauki na rynek pracy oceniła swoje predyspozycje przedsiębiorcze na poziomie co najmniej przeciętnym, co dotyczyło zarówno kobiet, jak i mężczyzn. Należy jednocześnie podkreślić, że ponad 1/4 respondentów oceniła swoje przedsiębiorcze predyspozycje niżej. Najsilniej odczuwana przez respondentów była potrzeba osiągnięć, co oznacza, że respondenci dążyli do osiągnięcia doskonałości. Studenci byli przekonani o własnym wpływie na podejmowane działania i osiągane rezultaty, jednak ich poczucie własnej wartości nie było wysokie, zwłaszcza w przypadku mężczyzn. Mężczyźni ocenili wyżej niż kobiety swoje możliwości podejmowania działań w nowy i wyjątkowy sposób.

Wyniki badań dowodzą, że studenci deklarowali cechy charakterystyczne dla osób przedsiębiorczych, jednak określić je należy jako umiarkowanie satysfakcjonujące, jeżeli uwzględni się potrzebę przedsiębiorczych działań w organizacji XXI w. Wskazują one także obszary problemowe, w których studenci i studentki ocenili swoje postawy niżej. W tych obszarach zatem kadra zarządzająca powinna podejmować działania pozwalające uzyskać pożądane rezultaty.

Wykorzystanie potencjału przedsiębiorczości młodych osób jest ważne dla pracodawcy, jednak aby działać skutecznie, niezbędne jest wspieranie inicjatyw przedsiębiorczych przez kreowanie określonych warunków zarówno na poziomie makroekonomicznym (w tym warunki instytucjonalne i społeczne) (Hendzel, 2007), jak i wewnątrz organizacji. Wyniki badań zrealizowanych przez innych autorów sugerują znaczącą rolę uczelni 
w kształtowaniu przedsiębiorczych postaw wśród studentów. Niezbędne jest pobudzanie przedsiębiorczości wśród studentów różnych kierunków, nie tylko ekonomicznych czy związanych z zarządzaniem. Pomocne w poszukiwaniu skutecznych rozwiązań są opinie respondentów, a także doświadczenia innych krajów, które dowodzą, że zarówno w zakresie treści kształcenia, jak i metod dydaktycznych istnieją rozwiązania umożliwiające nie tylko wyposażenie studenta w niezbędną wiedzę, ale także w kształtowanie jego przedsiębiorczych postaw i zachowań.

W okresie pracy zawodowej istotne stają się wiedza i umiejętności menedżerów w zakresie motywowania do aktywności, kształtowanie pozytywnych relacji interpersonalnych, a także kultury organizacyjnej, która umożliwia zaangażowanie się pracowników w działania przedsiębiorcze. Działania te są niezbędne w celu dostosowania się do zmieniającego się otoczenia, a to z kolei decyduje o przetrwaniu i rozwoju każdej organizacji. Stąd postaw przedsiębiorczych oczekuje się od kandydatów oraz pracowników na wszystkich szczeblach organizacji.

Wiedza na temat postaw przedsiębiorczych młodych osób jest cenna dla pracodawców, gdyż pozwala na oszacowanie „przedsiębiorczego potencjału” kandydatów i aktualnych pracowników, predykcję ich zachowań przedsiębiorczych. Jednocześnie stanowi podstawę zapewnienia warunków, które umożliwiają rozwój cech przedsiębiorczych, kreują zachowania przedsiębiorcze. Dla pracowników stanowi argument umożliwiający podjęcie decyzji dotyczącej dalszego ukierunkowania rozwoju zawodowego.

Badania opisane w artykule miały charakter pilotażowy. Przeprowadzono je na niedużej próbie - grupie studentów Wydziału Ekonomii Uniwersytetu Rzeszowskiego, co nie stanowi podstawy do uogólniania uzyskanych wyników dla studentów innych dyscyplin oraz studiujących w innych ośrodkach, a formułowanie wniosków należy ograniczać do badanej próby. $\mathrm{Na}$ odpowiedzi respondentów mogą wpływać również uwarunkowania kulturowe, status społeczno-ekonomiczny oraz inne charakterystyki, które nie zostały uwzględnione w badaniach.

Ponadto badania zawierają deklaracje respondentów, nie dotyczą podejmowanych działań, dlatego za wartościowe poznawczo należy uznać przeprowadzenie badań w okresie zatrudnienia studentów i porównanie deklaracji z przedsiębiorczą aktywnością.

Literatura

References

Arent, A., Walczyna, A. (2014). Przedsiębiorczość studentów - wyniki badań pilotażowych. W: E. Bojar, T. Żminda, J. Bis (red.), Region i edukacja a procesy rozwojowe. Lublin: Wydawnictwo Politechniki Lubelskiej, 133-144.

Autio, E., Keeley, R.H., Klofsten, M., Parker, G.G.C., Hay, M. (2001). Entrepreneurial Intent among Students in Scandinavia and in the USA. Enterprise and Innovation Management Studies, 2(2), 145-160. doi: 10.1080/14632440110094632

Bańka, A. (2016). Motywacja osiagnięć. Poznań-Warszawa: Stowarzyszenie Psychologia i Architektura, NFDK.

Bańka, A. (2007). Poradnictwo zawodowe w kształtowaniu przedsiębiorczości, kapitału kariery oraz zdolności zatrudnieniowej młodzieży. W: A. Biela (red.), Nauka pracy, doradztwo zawodowe i przedsiębiorczość młodzieży. Warszawa: Kancelaria Senatu, 52-64.

Bizon, W., Poszewiecki, A., Markiewicz, M., Skurczyński M. (2013). Budowanie postaw przedsiębiorczych wśród studentów. Założenia i przebieg projektu Case Simulator. W: M. Dąbrowski, M. Zając (red.), 
Rola e-edukacji w rozwoju kształcenia akademickiego. Warszawa: Fundacja Promocji i Akredytacji Kierunków Ekonomicznych, 75-83.

Bohdziewicz, P. (2010). Współczesne kariery zawodowe: od modelu biurokratycznego do przedsiębiorczego. Zarzadzanie Zasobami Ludzkimi, 3-4, 39-56.

Braziene, R., Merkys, G., Mikutaviciene, I. (2014). Employers' Expectations and Young Workers Selection Criteria in Lithuania. Social Sciences, 4(86), 62-69. doi: 10.5755/j01.ss.86.4.9226

Buchta, K., Jakubiak, M. (2014). Determinanty postaw przedsiębiorczych studentów jako element innowacyjności w procesie kształcenia. Zeszyty Naukowe WSEI. Seria: Ekonomia, 9(2), 167-179.

Cieślik, J. (2014). Iluzje innowacyjnej przedsiębiorczości. Kwartalnik Nauk o Przedsiębiorstwie, 3, 4-16.

Dąbrowska, K., Skowron, M. (2015). Porównanie postaw przedsiębiorczych studentów studiów ekonomicznych, społecznych i humanistycznych. Annales. Etyka w życiu gospodarczym / Annales. Ethics in Economic Life, 18(3), 121-131.

Gołębiewska, B. (2009). Wybrane zagadnienia $z$ ekonomiki przedsiębiorstw turystycznych, Warszawa: Wydawnictwo SGGW.

Góralewska-Słońska, A. (2011). Poczucie własnej wartości jako potencjał jednostki. Problemy Profesjologii, 2, 97-112.

GUS. (2019). Aktywność ekonomiczna ludności Polski. I kwartał 2019 r. Warszawa: GUS. Pozyskano z: https:// stat.gov.pl/obszary-tematyczne/rynek-pracy/pracujacy-bezrobotni-bierni-zawodowo-wg-bael/ aktywnosc-ekonomiczna-ludnosci-polski-i-kwartal-2019-roku,4,33.html

Guthridge, M., Komm, A.B., Lawson, E. (2008). Making talent a strategic priority. The McKinsey Quarterly, 1. Pozyskano z: http://www.leadway.org/PDF/Making\%20talent\%20a\%20strategic\%20 priority.pdf

Hendzel, D. (2007). Możliwości kształtowania postaw przedsiębiorczych w organizacji gospodarczej. W: P. Wachowiak, M. Dąbrowski, B. Majewski (red.), Kształtowanie postaw przedsiębiorczych a edukacja ekonomiczna. Warszawa: Fundacja Promocji i Akredytacji Kierunków Ekonomicznych, $17-23$.

Infuture Institute. (2019, 3 września). Pracownik przyszłości. Gdańsk. Pozyskano z: http://infuture.institute/raporty/pracownik-przyszlosci

Kauffman. The Foundation of Entrepreneurship. (2019). Entrepreneurship in American Higher Education. A Report from the Kauffman Panel on Entrepreneurship Curriculum in Higher Education. Pozyskano z: https://www.kauffman.org/wp-content/uploads/2019/12/entrep_high_ed_report.pdf

Kapusta, F. (2006). Przedsiębiorczość - teoria i praktyka. Poznań: Wydawnictwo Wyższej Szkoły Zarządzania i Bankowości w Poznaniu.

Klonowska-Matynia, M., Palinkiewicz, J. (2013). Przedsiębiorczość w teorii ekonomicznej. Zeszyty Naukowe Wydziału Nauk Ekonomicznych Politechniki Koszalińskiej, 17, 29-40.

Koptiew, D. (2014). Sytuacja grup defaworyzowanych na rynku pracy w Polsce - osoby młode versus osoby starsze. Przedsiębiorczość i Zarzadzanie, XIV(1/1), 233-247.

Korpysa, J. (2007). Uwarunkowania przedsiębiorczości studentów - rezultaty badań. W: D. Kopycińska (red.), Wykorzystanie zasobów pracy we wspótczesnej gospodarce. Szczecin: Wydawnictwo Naukowe Katedry Mikroekonomii Uniwersytetu Szczecińskiego, 228-236.

Kraśnicka, T., Głód, G., Ludvik, L., Peterkova, J. (2014). Uwarunkowania intencji przedsiębiorczych studentów uczelni ekonomicznych Polski i Czech. Przedsiębiorczość - Edukacja [Entrepreneurship - Education], 10, 316-332.

Lendner, C., Hübscher, J. (2009). Lerneffekte bei Gründern und Studenten durch GründungsmanagementComputersimulationen. ZfKE - Zeitschrift für KMU und Entrepreneurship, 57(3-4), 259-279.

Łochnicka, D. (2016). Przedsiębiorczość pracownicza i jej wplyw na efektywność organizacji. Łódź: Wydawnictwo Uniwersytetu Łódzkiego.

Łuczka, T. (2011). Przedsiębiorczość i postawy przedsiębiorcze studentów: wybrane aspekty. Zeszyty Naukowe Uniwersytetu Szczecińskiego. Ekonomiczne Problemy Usług, 63, 150-158. 
Mackenzie Davey, K., Arnold, J. (2000). A multi-method study of accounts of personal change by graduates starting work: Self-ratings, categories and women's discourses. Journal of Occupational and Organizational Psychology, 73, 461-486. doi: 10.1348/096317900167164

Moczydłowska, J.M., Pycz, E. (2017). Uwarunkowania przedsiębiorczości studentów (na przykładzie studentów Wydziału Zarządzania Politechniki Białostockiej). Akademia Zarządzania, 1, 73-88.

Oleksyn, T. (2006). Zarzązanie kompetencjami. Teoria i praktyka. Kraków: Oficyna Ekonomiczna.

PARP. (2019a, 23 września). Monitoring innowacyjności polskich przedsiębiorstw. Wyniki II edycji badania. Warszawa. Pozyskano z: https://www.parp.gov.pl/component/publications/publication/monitoring-innowacyjnosci-polskich-przedsiebiorstw-wyniki-ii-edycji-badania-2019

PARP. (2019b, 23 września). Raport o stanie sektora małych i średnich przedsiębiorstw. Warszawa. Pozyskano z: https://www.parp.gov.pl/storage/publications/pdf/2019_07_ROSS.pdf

Piecuch, T. (2013). Przedsiębiorczość. Podstawy teoretyczne. Warszawa: Wydawnictwo C.H. Beck.

Pluta, J., Safin, K. (2016). Ścieżki kariery a przedsiębiorczość ludzi młodych. Horyzonty Wychowania, 15(35), 177-197. doi: 10.17399/HW.2016.153509

Podrug, N., Vrdoljak Raguž, I., Dedić, M. (2015; 2020, 27 lipca). Comparative analysis of entrepreneurial orientation of Croatian and Sweden students. DIEM: Dubrovnik International Economic Meeting, 2(1), 186-201. Pozyskano z: https://hrcak.srce.hr/161599

Reykowski, J. (1977). Z zagadnień psychologii motywacji. Warszawa: Wydawnictwa Szkolne i Pedagogiczne.

Robinson, P.B., Stimpson, D.V., Huefner, J.C., Hunt, H.K. (1991). An attitude approach to the prediction of entrepreneurship. Entrepreneurship Theory and Practice, 15, 13-31. doi: $10.1177 / 104225879101500405$

Savickas, M.L., Nota, L., Rossier J., Dauwalder, J.-P., Duarte, M.E., Guichard, J., Soresi, S., van Esbroeck, R., van Vianen, A.E.M. (2009). Life designing: A paradigm for career construction in the 21st century. Journal of Vocational Behavior, 75(3), 239-250. doi: 10.1016/j.jvb.2009.04.004

Sobczyk, M. (2000). Statystyka. Podstawy teoretyczne - przykłady, zadania. Lublin: Wydawnictwo UMCS.

Sturges, J., Guest, D., Mackenzie Davey, K. (2000). Who's in charge? Graduates' attitudes to and experiences of career management and their relationship with organizational commitment. European Journal of Work and Organizational Psychology, 9, 351-371. doi: 10.1080/135943200417966

Vinig, T.G., Dorresteijn, W. (2007; 2020, 27 lipca). Determinants of Entrepreneurial Orientation Among Students - A Comparative Study of Dutch, Norwegian and Israeli Students. Pozyskano z: https:// ssrn.com/abstract $=1020576$

Wiatrak, A.P. (2003). Pojęcie przedsiębiorczości, jej cele i rodzaje. W: K. Jaremczuk(red.), Uwarunkowania rozwoju przedsiębiorczości - szanse i zagrożenia. Tarnobrzeg: Wydawnictwo PWSZ, 26-38.

Wiatrowski, Z. (2009). Dorastanie, dorosłość i starość człowieka w kontekście działalności i kariery zawodowej. Radom: Instytut Technologii Eksploatacji - PIB.

Widerszal-Bazyl, M. (1979). Ukierunkowanie motywacji osiagnięć a poziom wykonania pracy. WrocławWarszawa-Kraków-Gdańsk: Wydawnictwo Polskiej Akademii Nauk.

Wojdyło, K., Retowski, S. (2012). Kwestionariusz celów związanych z osiągnięciami (KCO) - konstrukcja i charakterystyka psychometryczna. Przegląd Psychologiczny, 55(1), 9-28.

World Economic Forum. (2009). Educating the Next Wave of Entrepreneurs. Unlocking entrepreneurial capabilities to meet the global challenges of the 21st Century. A Report of the Global Education Initiative. Pozyskano z: file://C:/Users/A4231 1.PRY/AppData/Local/Temp/SSRN-id1396704. pdf

Wyrwa, D., Sołtysiak, M. (2016). Przedsiębiorczość akademicka - postawy przedsiębiorcze studentów. Zeszyty Naukowe PWSZ w Płocku. Nauki Ekonomiczne, XXIV, 259-270.

Żur, A. (2006). Intraprzedsiębiorczość jako innowacyjna koncepcja zarządzania. Zeszyty Naukowe Akademii Ekonomicznej w Krakowie, 730, 131-140. 
Anna Mazurkiewicz, dr, adiunkt w Instytucie Ekonomii i Finansów Uniwersytetu Rzeszowskiego. Jej zainteresowania naukowe koncentrują się wokół zagadnień związanych z zarządzaniem pracownikami utalentowanymi i zarządzaniem karierą. Jest autorką publikacji naukowych z zakresu zarządzania, dotyczących zwłaszcza znaczenia kapitału ludzkiego we współczesnej organizacji i wiceprzewodniczącą Podkarpackiego Stowarzyszenia Organizacji i Zarządzania.

Anna Mazurkiewicz, PhD, assistant professor in the Institute of Economics and Finance at the University of Rzeszów. Her research interests focus on issues related to talented staff management and career management. She is the author of several publications on management, especially regarding the importance of human capital in contemporary organisations and is Vice-chairman of the Podkarpackie Association of Organization and Management.

ORCID: https://orcid.org/0000-0003-2764-284X

\section{Adres/Address:}

Uniwersytet Rzeszowski

Kolegium Nauk Społecznych

Instytut Ekonomii i Finansów

Katedra Ekonomiki i Zarządzania

ul. Ćwiklińskiej 2

35-601 Rzeszów, Poland

e-mail: annam@ur.edu.pl 